\title{
Imagem e movimento: o modo visual na construção da identidade do sem-terra ${ }^{1}$
}

\author{
Image and movement: the visual mode in \\ the identity construction of landless workers
}

Vanderlei J. Zacchi*

Universidade Federal de Sergipe - UFS

\begin{abstract}
RESUMO: Estudos sobre os multiletramentos têm chamado a atenção para a crescente importância de habilidades não-verbais no processo de aprendizagem e de construção de identidade, principalmente com o advento das novas tecnologias de comunicação. As habilidades, ou modos de produção de significado, mais importantes são cinco: visual, auditiva, gestual, espacial e multimodal. O objetivo deste trabalho é analisar o visual como modo de produção de significado e sua relação com o modo linguístico nas mídias do MST. Embora o movimento coloque grande ênfase no verbal, o trabalho com imagens pode ser visto também como fonte de empoderamento e construção de identidade do sem-terra.
\end{abstract}

PALAVRAS-CHAVE: multiletramentos, multimodalidade, mídia, MST

ABSTRACT: Studies on multiliteracies have been placing great emphasis on nonverbal skills in learning and in identity construction, especially with the rise of new technologies of communication. The most significant skills, or modes of meaning-making, are five: the visual, the audio, the spatial, the gestural and the multimodal. This paper aims at analysing the visual as a mode of meaning-making and its interaction with the linguistic mode in the MST's electronic and print media. Although the landless movement places great emphasis on the writtentextual mode, it has been highly skilful in dealing with images in ways which contribute to the empowerment and identity construction of the landless.

KEYWORDS: multiliteracies, multimodality, media, landless movement.

\section{Introdução}

Estudos recentes em linguística aplicada têm colocado grande ênfase no uso de novas mídias e na interação de diferentes técnicas e habilidades no

\footnotetext{
${ }^{1}$ Este texto é resultante de pesquisa de doutorado no programa de Estudos Linguísticos e Literários em Inglês da USP, sob a orientação da Profa. Dra. Walkyria Monte Mór. Agradeço à Capes pela concessão da bolsa Prodoutoral durante o período da pesquisa.

*vanderlei@ufs.br
} 
processo de aprendizagem e de construção de identidade. Para além do texto escrito, aspectos visuais, digitais e sonoros passam a desempenhar papel fundamental. Da mesma maneira, leitura e escrita se mesclam com outras habilidades como a auditiva, a visual e a espacial, intensificadas pelos meios de comunicação de massa, especialmente com o advento do computador e da Internet. Essa visão está na base dos estudos sobre multiletramentos e multimodalidade (BRASIL, 2006; COPE; KALANTZIS, 2000; KRESS, 2000; KRESS; VAN LEEUWEN, 2006; MENEZES DE SOUZA, 2005; MONTE MÓR, 2006). Segundo Cope e Kalantzis (2000, p. 5), essas habilidades são também "modos de produção de significado", pois se caracterizam como recursos semióticos em situações de comunicação e representação. Os modos de produção de significado que estão adquirindo maior grau de importância são cinco: visual, auditivo, gestual, espacial e multimodal. Este último refere-se à integração de todos os anteriores, incluindo também o tradicional modo linguístico. Cope e Kalantzis (2000, p. 5) argumentam que estão em processo uma multiplicidade e integração crescentes de modos de produção de significados, "em que o textual está relacionado também com o visual, o sonoro, o espacial, o comportamental, entre outros. Isso é particularmente importante nos meio de comunicação de massa, na multimídia e na hipermídia eletrônica". ${ }^{2} \mathrm{O}$ significado seria, portanto, produzido de maneira cada vez mais multimodal. As Orientaçôes Curriculares para o Ensino Médio relativas a conhecimentos de línguas estrangeiras atribuem a cada uma dessas habilidades o termo letramento, que se refere a "práticas socioculturais contextualizadas" (BRASIL, 2006, p. 106), em oposição a práticas tradicionais que buscam promover a aquisição de conhecimento num ambiente descontextualizado e deslocado do meio sociocultural do usuário. $\mathrm{Na}$ interação dessas diversas habilidades, criou-se o conceito de multiletramentos, "para dar conta da extrema complexidade desses novos e complexos usos da linguagem por novas comunidades de prática".

Esse novo enfoque traz para o primeiro plano habilidades já dominadas por grupos minoritários e que agora tomam novo significado. A comunicação visual, por exemplo, sempre desempenhou papel importante entre grupos indígenas (MENEZES DE SOUZA, 2005). O presente trabalho tem como objetivo analisar algumas das produçóes visuais do Movimento dos

\footnotetext{
${ }^{2}$ A tradução de textos originalmente em língua estrangeira é de minha responsabilidade.
} 
Trabalhadores Rurais Sem Terra (MST), desde sua bandeira até imagens retiradas de suas mídias. Isso não quer dizer que os demais modos de produção de significado sejam irrelevantes na maneira como o movimento se autorrepresenta. A webpage do MST, por exemplo, congrega vários desses modos, uma vez que o texto escrito interage com imagens, vídeos e mensagens gravadas em áudio. Entretanto, por uma questão de espaço, tratarei aqui principalmente do aspecto visual e de sua relação com o modo linguístico. $\mathrm{O}$ uso de imagens contribui para a construção da identidade do sem-terra, em especial de duas maneiras: internamente, como forma de dar coesão ao grupo e, externamente, como autorrepresentação, que procura delinear os perfis do sem-terra e convidar os espectadores a se identificarem com ele.

Na seção seguinte, após um breve histórico sobre o MST, será feita uma discussão sobre a construção da identidade coletiva por meio do modo visual a partir da noção de multimodalidade. Na sequência, serão analisadas algumas imagens que foram escolhidas, tendo-se em mente essa construção identitária. Primeiramente, a bandeira e seu logotipo, pois se constituem provavelmente na imagem do MST mais veiculada pela mídia em geral e pelo próprio movimento. Como resultado, a bandeira transformou-se num poderoso ícone de autorrepresentação do sem-terra. Em seguida, serão analisadas as capas de duas ediçôes da Revista Sem Terra. A razão de sua escolha deve-se ao fato de que, de alguma maneira, as imagens nelas impressas demonstram uma busca pelo MST de atrair pessoas cuja identificação com o movimento não é imediatamente óbvia, pois utilizam uma linguagem mais abstrata que em muito difere de seu discurso ativista, fortemente centrado no modo verbal. Por fim, será examinada a relação entre fotos e legendas em algumas imagens também retiradas de exemplares da revista. Essa relação demonstra que em muitos casos o modo visual e o verbal entram em conflito, produzindo uma mensagem fraturada, o que, de certa forma, reflete a heterogeneidade conflituosa própria das identidades coletivas.

\section{Imagem e identidade}

A consolidação do MST como um movimento político organizado se deu em 1984 (HISTORY..., 2003), ainda no período do governo militar. O primeiro congresso do movimento, no ano seguinte, reuniu mais de 1.500 delegados, representando os sem-terra de 23 estados. Mas os participantes não se limitavam aos trabalhadores rurais. Segundo Branford e Rocha (2004, p. 52), 
entre eles havia ainda parlamentares, representantes de ONGs, líderes indígenas, delegados de confederações camponesas da América Latina, líderes sindicais, bispos católicos e ministros luteranos. Além da heterogeneidade na composição dos participantes, era preocupação do movimento, desde o início, que sua luta se tornasse nacional, não se limitando aos estados do sul do país, onde o MST se originou a partir de conflitos agrários envolvendo trabalhadores rurais na década de 1970 . Outro aspecto importante para o movimento na época de sua fundação era manter sua autonomia em relação a outros atores sociais já estabelecidos. Houve quem defendesse a atuação dos sem-terra na esfera de partidos políticos ou centrais sindicais. Para outros, deveriam ficar sob a proteção da Igreja Católica, que teve papel fundamental na fundação do movimento através da Comissão Pastoral da Terra (CPT). Logo se deram conta, entretanto, de que estariam, dessa maneira, excluindo ativistas de outras igrejas, como a luterana, que também apoiavam as causas dos sem-terra. A tese da autonomia acabou prevalecendo, mas a interação com outros atores sociais se manteve, pois muitas de suas reivindicações coincidem com as do movimento. O MST tem ainda o apoio de organizaçóes solidárias, distribuídas por catorze países em várias partes do mundo (QUIRK, 2007). Essa heterogeneidade na formação e constituição do movimento é ilustrativa da complexidade identitária do sem-terra, que é geralmente reconhecida pelo movimento. Ao mesmo tempo, porém, o próprio MST esforça-se em representar o sem-terra como um sujeito coletivo unitário, congregado em torno de símbolos únicos como o hino e a bandeira.

Hoje o MST tem aproximadamente 1.500 .000 de membros e está presente em 23 estados do Brasil (QUIRK, 2007). Já foram oficializados cerca de 2.300 assentamentos, onde funcionam 88 cooperativas e 96 agroindústrias, além de 1.800 escolas de ensino médio e fundamental. Recentemente, foi inaugurada também a Escola Nacional Florestan Fernandes, em São Paulo, voltada para o ensino superior dos sem-terra e de outros grupos sociais menos privilegiados. A estrutura organizativa do movimento é baseada num conjunto de setores e coletivos (ABOUT..., 2006), tais como: Produção, Cooperação e Meio Ambiente; Educação e Formação Política; Gênero; Comunicação; Saúde; Direitos Humanos; Relações Internacionais; Cultura. O movimento tem duas publicaçõos periódicas: o Jornal Sem Terra, de circulação mensal, foi fundado há 27 anos; e a Revista Sem Terra, bimestral, começou a circular há doze anos. Há ainda uma emissora de rádio virtual, a Vozes da Terra. O acesso a ela pode ser feito pela webpage do movimento, www.mst.org.br, criada em 1996, e disponível também em sete línguas estrangeiras. Em entrevista gravada, 
Maria Lúcia, ${ }^{3}$ integrante do setor de comunicação do movimento, explica que, enquanto o jornal é direcionado aos integrantes do movimento, a revista e a mídia virtual são voltadas para o público em geral. Pelo seu dinamismo, a Internet permite mais flexibilidade e rapidez na produção das notícias em comparação com os meios impressos. Segundo a entrevistada, a página serve como uma vitrine para a atuação do movimento e surgiu com o propósito de informar a população sobre questões que normalmente não são noticiadas pela grande imprensa, mais propensa a enfatizar os aspectos negativos do movimento.

Conforme mencionado acima, o MST esforça-se em representar o semterra como um sujeito coletivo unitário, embora sua formação seja marcadamente heterogênea. Essa heterogeneidade é própria da identidade coletiva, segundo a definição de Castells:

No que diz respeito a atores sociais, entendo por identidade o processo de construção de significado com base em um atributo cultural, ou ainda um conjunto de atributos culturais inter-relacionados, o(s) qual(ais) prevalece $(\mathrm{m})$ sobre outras fontes de significado. Para um determinado indivíduo ou ainda um ator coletivo, pode haver identidades múltiplas. No entanto, essa pluralidade é fonte de tensão e contradição tanto na auto-representação quanto na ação social. (1999, p. 22)

Castells afirma ainda que toda identidade é construída a partir de elementos fornecidos pelas mais variadas fontes - história, biologia, memória coletiva, aparatos de poder, entre outros. Cabe aos grupos sociais, segundo ele, processar todo esse material e reorganizar seu significado "em função de tendências sociais e projetos culturais enraizados em sua estrutura social” (p. 23). A discussão a seguir procura mostrar que a multimodalidade ajuda a modelar a identidade do sem-terra também pelo fato de ser fonte de pluralidade e tensão principalmente na autorrepresentação do movimento.

Apesar da crescente integração entre os diferentes modos de produção de significado, existe ainda uma tendência em mantê-los separados, colocando-se mais ênfase no modo linguístico. Essa separação, no entanto, vem sendo desafiada pelas novas tecnologias de comunicação. Ao falar sobre as mídias do MST, Maria Lúcia afirma que o "conteúdo" é mais importante

\footnotetext{
${ }^{3}$ Nome fictício. Entrevista realizada em 26 de junho de 2007 e gravada em arquivo MP3.
} 
que o visual, que é visto apenas por seu valor estético. Para ela, as pessoas têm de ter fácil acesso ao conteúdo, pois é ele, e não o visual, que atrai as pessoas. "A página tem que ser bonita, mas funcional", afirma ela. A primazia do modo linguístico é descrita por Kress da seguinte maneira:

[e]xiste uma tendência geral em se considerar a língua como um meio comunicativo e representacional totalmente adequado à expressão de qualquer coisa que queiramos expressar: que qualquer coisa que pensemos ou sintamos pode ser dita (ou escrita) através da língua. $O$ outro lado dessa ideia é que, se alguma coisa não pode ser expressa através da língua (se tal coisa existisse), então essa coisa está, de qualquer maneira, fora do pensamento racional, fora do sentimento articulado e, portanto, não precisa ou não deveria ser dita. Essa pressuposição está ancorada no senso comum tanto popular quanto teórico; inúmeras investigações teóricas a reproduzem e a reforçam constantemente (2000, p. 193).

Rodowick (2001, p. 31) argumenta que a separação entre o visual e o verbal tem profundas raízes no Iluminismo do século 18 . Do ponto de vista do racionalismo iluminista, o verbal era o único modo encarregado da significação e da comunicação, enquanto o visual ficava relegado exclusivamente ao campo da estética. Segundo o autor, essa fronteira entre expressão visual e verbal ainda prevalece nos dias de hoje, mas vem sendo constantemente desafiada pelas "qualidades híbridas" (p. 37) das artes cinematográficas e digitais. A excessiva importância que vem sendo dada à cultura letrada nos últimos tempos, à qual boa parte dos sem-terra não tem acesso, reflete também esse problema, o que permite afirmar que a comunicação visual entre os sem-terra tem grande potencial para ser intensificada. No entanto, a multimodalidade pressupóe que todos os modos de representação fazem parte de um texto integrado. Segundo Kress e Van Leeuwen (2006, p. 177), uma figura não é apenas uma "ilustração" do texto verbal, nem o texto verbal e o visual são tratados como elementos separados. Portanto, o conteúdo não está apenas no verbal, mas no todo. Mesmo assim, o texto integrado não pressupõe harmonia total. Em alguns casos, o verbal pode estar transmitindo um conjunto de significados e o visual, outro (p. 20). Esse conflito é parte integrante, portanto, da significação global do texto. Pensar a identidade coletiva do MST como multimodal é levar em conta essa tensão. Ao mesmo tempo em que a multimodalidade fornece maiores possibilidades de autorrepresentação, também instrumentaliza o receptor do texto com mais possibilidades de 
interpretação. Assim, a forte ênfase que o movimento coloca sobre o modo linguístico como um meio de transmissão de sua mensagem ao tentar construir uma identidade unitária coerente é relativizada pela introdução de outros modos de produção de significado, o que pode se tornar uma fonte a mais de contradiçōes a caracterizar a heterogeneidade do sem-terra.

Para Maria Lúcia, entretanto, é a mensagem linguística que deve atrair o leitor, pois ali, na página do MST, ele teoricamente vai se deparar com abordagens incomuns, pouco prováveis de serem encontradas nos meios de comunicação a que as pessoas estão normalmente expostas, "re-significando" assim o movimento. A escolha das fotos é usada na tentativa de reforçar a identidade militante do sem-terra. A entrevistada compara o tratamento dado a uma notícia por uma agência de notícias com a maneira como ela é abordada pelo MST. Ela se refere à webpage, mas essa visão pode se estender também às mídias impressas do movimento, principalmente porque nelas há uma presença maior de fotos. No caso de uma notícia sobre a transposição do Rio São Francisco, por exemplo, diz ela, uma agência normalmente colocaria uma foto de um ministro falando, ao passo que o MST mostraria uma foto de pessoas manifestando-se contra a transposição. Numa notícia sobre transgênicos, uma agência exibiria a foto de uma espiga de milho, enquanto que o MST, a de pessoas protestando. Maria Lúcia explica: "o interessante pra gente é mostrar as pessoas protestando contra o milho transgênico, mesmo que a matéria não esteja falando do protesto e que o protesto tenha sido um ano atrás". Ainda que, aparentemente, as fotos possam estar apenas servindo como ilustração para o texto escrito, a presença delas por si só oferece uma outra leitura, evidente na comparação: não há como afirmar neutralidade nos meios de comunicação. A diferença é que as agências de notícias tendem a proclamar uma postura neutra, enquanto o MST procura ser mais claro quanto a sua posição. Em jogo estão questôes de poder e ideologia:

consideramos qualquer tipo de imagem como totalmente pertencente à esfera das realizações e instanciações da ideologia, como um meio sempre - para a articulação de posiçôes ideológicas. A questão é que nem o poder nem o seu uso desapareceram. Simplesmente ficou mais difícil seguir seu traçado e localizá-lo. Nesse contexto há uma necessidade absoluta, em termos democráticos, de tornar disponíveis os meios para se entender as articulações do poder em qualquer lugar, em qualquer forma (KRESS; VAN LEEUWEN, 2006, p. 14). 
O modo visual desempenha um importante papel na forma como o MST se representa. Ele é significativo tanto nos símbolos que o movimento elabora na tentativa de definir uma identidade, como o logotipo e a bandeira, quanto nas fotos e imagens de suas mídias, que também são o resultado de uma escolha e de uma representação de mundo. A criação desses "ícones emblemáticos" são, para Gohn (2000, p. 157), um item diferenciador do movimento, quando comparado com outros grupos latino-americanos, como o Sendero Luminoso, do Peru, ou os zapatistas do México, que não adotaram identificadores visuais semelhantes.

\section{A bandeira}

A bandeira e o logotipo - que exibe um casal do qual o homem segura um facão para o alto (vide FIG. 1) - foram escolhidos em 1987 (ABOUT..., 2006), pouco tempo após a criação do movimento. Uma das opções para a adoção de um logotipo que se tornasse um símbolo do MST era o chapéu de palha, que foi recusado por ser considerado saudosista (BRANFORD; ROCHA, 2004, p. 328). O contraste com outros tipos de chapéu como determinantes de identidade é evidente, principalmente o chapéu de cowboy dos rodeios norte-americanos, largamente utilizados também no Brasil. A escolha do símbolo do MST reflete ainda um conflito identitário entre representar os sem-terra como pessoas do campo, trabalhadores rurais, e representá-los como militantes que lutam por transformaçōes.

No caso específico do logotipo e da bandeira, a segunda opção foi a escolhida. O facão segurado pelo homem pode ser considerado um vetor (FIG. 1).

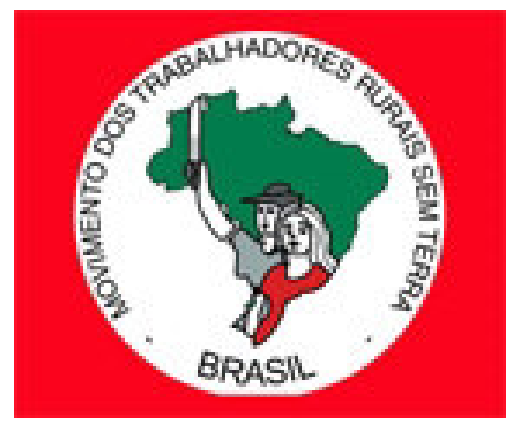

FIGURA 1 - Bandeira do MST

Vetores, na definição de Kress e Van Leeuwen (2006, p. 46), são os correspondentes visuais dos "verbos de ação" da linguística. Para os autores, eles 
indicam também processos narrativos, em oposição a processos conceituais. Nestes, os participantes são representados "em termos de uma essência generalizada e mais ou menos estável e atemporal” (p. 59). O chapéu de palha representaria, assim, um processo conceitual. A escolha de um casal segurando um facão, por sua vez, indica uma opção por "processos de transformação", ou "açôes e eventos que se desdobram" (KRESS; VAN LEEUWEN, 2006, p. 59). Essa parece ser uma tendência nas imagens produzidas pelo movimento. No exemplo do milho transgênico mencionado acima, o processo narrativo de uma foto dos sem-terra em cenas de militância tem preferência sobre o processo conceitual de uma imagem de uma espiga de milho. $O$ facão para o alto pode também ser lido como pertencente ao domínio do ideal. $\mathrm{Na}$ análise semiótica das imagens, Kress e Van Leeuwen (2006, p. 186) afirmam que, em geral, a parte superior representa o ideal, enquanto a inferior, o real. Nesse caso, o facão funciona como metonímia tanto para "trabalho" quanto para "luta", como se pode ler na descrição dos elementos da bandeira expostos pelo MST:

[o] mapa do Brasil representa o MST como uma organização nacional e que a luta pela reforma agrária deveria envolver o país todo.

$\mathrm{O}$ trabalhador e a trabalhadora representam a necessidade de engajar homens, mulheres e famílias inteiras na luta.

O facão representa as ferramentas de trabalho, luta e resistência dos sem-terra brasileiros. [...]

A cor branca representa a paz pela qual lutamos, que só poderá ser conquistada quando houver justiça social para todos.

A cor vermelha representa o sangue que corre em nossas veias e nossa vontade de lutar pela reforma agrária e pela transformação da sociedade. A cor preta representa nossa homenagem a todos aqueles trabalhadores que já sucumbiram na luta pela nova sociedade.

A cor verde representa a esperança de vitória sobre toda propriedade grande e improdutiva que devemos conquistar (ABOUT..., 2006).

Considerando-se o homem e a mulher separadamente, pode-se classificar o homem como ator (KRESS; VAN LEEUWEN, 2006, p. 74) e a mulher como acompanhamento (p. 75) - já que é ele quem empunha o facão (o meio do processo narrativo) - numa ação não-transacional (p. 74), quando o vetor emana de um participante mas não aponta para outro. Essa característica reforça a afirmação de Kress e Van Leeuwen (p. 67-68) de que é comum, principalmente em publicidade, o homem ser representado como o protagonista e a mulher como coadjuvante. No caso dos sem-terra, essa representação trai os esforços do movimento de dar tratamento igual aos dois gêneros (MULHER..., 2006). 
Por outro lado, se a leitura feita pelo MST - a do casal como representante da família - for privilegiada, tanto o homem quanto a mulher integram, juntos, $\mathrm{o}$ ator, o que não anula o papel de coadjuvante designado a ela. Ambos podem ser vistos como um Adão e Eva, não no Jardim do Éden, mas no papel do casal primordial que vai dar muitos frutos, simbolizando, portanto, fertilidade e trabalho em sinergia com a terra que semeiam.

A cor vermelha da bandeira é outro elemento que comporta uma leitura alternativa à apresentada pelo movimento. Não é difícil relacioná-la a grupos socialistas e esquerdistas, que têm historicamente feito uso dessa cor como forma de representação. A "transformação da sociedade" não seria somente resultado do "sangue" e do "anseio" do sem-terra mas também da implantação de um modelo socialista de organização política e sociocultural. Observandose as imagens produzidas pelo MST, nota-se que o vermelho é a cor dominante. Ela está presente na bandeira, nas camisetas, bonés e faixas dos semterra, além de ser a cor com maior destaque na homepage do movimento. A explicação para a cor negra ecoa traços de martirização e teleologia, por salientar o sacrifício dos que "tombaram na luta por uma nova sociedade", o que se assemelha a uma cruzada, ou a uma narrativa épica de fundo cristão. Encontramse, portanto, nessas representações, incluindo-se também as descrições das cores branca e verde, dois elementos-chave na formação identitária do MST: o socialismo e o cristianismo, com um forte teor de utopia. Chama a atenção, ainda a necessidade que o movimento demonstra de explicar com palavras todas as imagens. Uma vez mais, o linguístico sobrepõe-se ao visual. No entanto, é a bandeira que é massivamente veiculada, ela que está em quase todas as fotos dos sem-terra. Nesse caso, a imagem é portadora de uma capacidade de significar muito maior que a do texto escrito. Assim como os contextos em que ela emerge, as possibilidades de interpretação são mais diversas.

Um outro vetor pode ser identificado na figura do casal. Segundo Kress e Van Leeuwen (2006, p. 117), o olhar do participante em direção ao espectador forma um tipo de vetor que estabelece um elo entre eles. Nesse caso, o participante não se configura como um ator, mas um reator (p. 75). Na FIG. 1, há uma reação não-transacional (p. 74), pois o vetor não está voltado para outro participante da imagem. Se os dois participantes estivessem olhando um para o outro, numa reação transacional, os efeitos seriam bastante diversos. A reação não-transacional nessa figura cria uma empatia com o espectador, convidandoo a identificar-se com o sem-terra e, nesse caso, solidarizar-se com sua luta. Esse aspecto será analisado em outras imagens a seguir e é importante na medida 
que contrasta fortemente com as imagens de manifestações tão frequentes nas mídias do MST.

\section{Um olhar para fora}

Como na FIG. 1, os olhares dos participantes das FIG. 2 e 3 abaixo formam um vetor em direção ao exterior da imagem, criando um elo com o espectador. Para Kress e Van Leeuwen (2006, p. 118), esse tipo de imagem é classificado como "demanda", pois o olhar do participante exige algo do espectador, que ele entre em algum tipo de relação imaginária com o participante. Em contraste, a imagem do gênero "oferta" - quando não ocorre esse contato - coloca o espectador como observador apenas e os participantes como mera informação. A demanda, segundo os autores (p. 264), foi conscientemente utilizada por Bertolt Brecht no teatro e por Jean-Luc Godard no cinema, para criar um "efeito de alienação" e romper com as convenções do mundo ficcional. O objetivo seria deixar claro aos espectadores que eles estão diante de uma obra ficcional, convidando-os a refletir sobre seu conteúdo. Manovich (2001) argumenta que essa estratégia é parte integrante da interação com computadores: "[a] reaparição periódica da máquina, a presença contínua do canal de comunicação na mensagem, previnem que o sujeito caia no mundo onírico da ilusão por muito tempo e fazem com que ele alterne entre concentração e desprendimento" (p. 207).

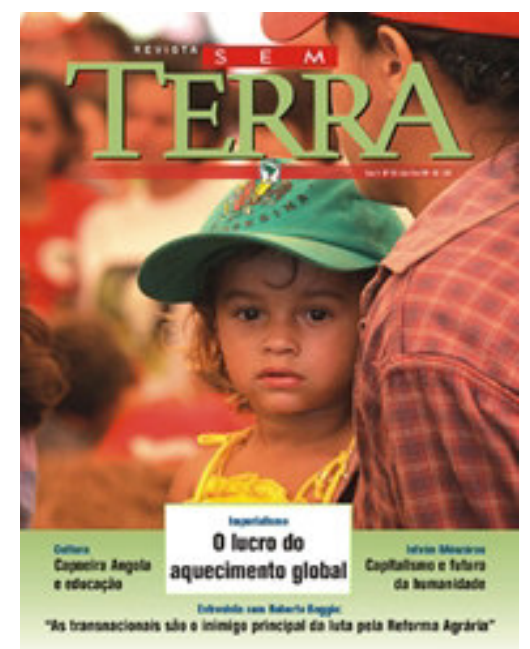

FIGURA 2 - Capa da Revista Sem Terra (set./out. 2007) 


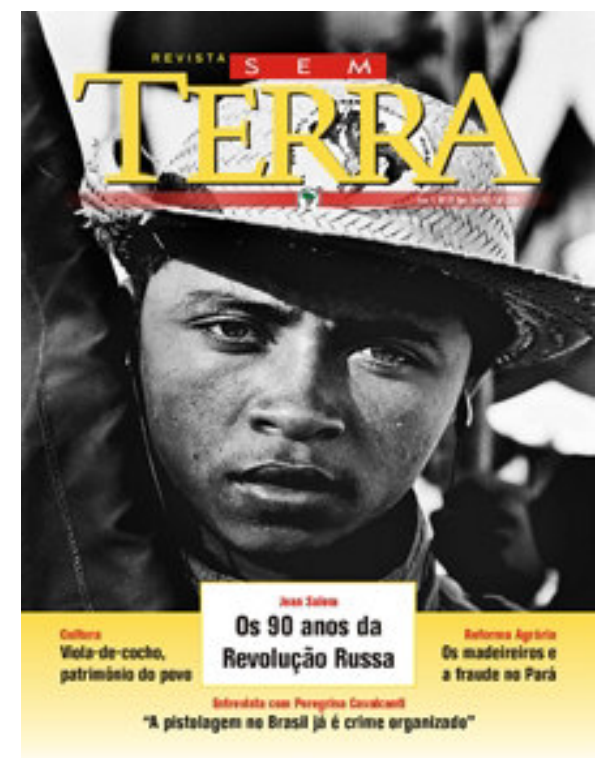

FIGURA 3 - Capa da Revista Sem Terra (nov./dez. 2007)

A demanda nas fotos da Revista Sem Terra convida o espectador a se envolver com os participantes, e não tratá-los, descompromissadamente, como um mero objeto estético, social ou antropológico. Essa característica é realçada ou atenuada por outros aspectos presentes nessas duas fotos, que as tornam singulares no contexto das produções visuais do MST, em geral dominadas por imagens de manifestações e confrontos. Há um certo lirismo nelas pouco comum nas páginas do movimento. $\mathrm{O}$ primeiro desses aspectos refere-se ao ângulo em que os representantes são mostrados, que também tem uma relação direta com o grau de envolvimento do produtor e / ou espectador da imagem. Nas duas fotos acima, o ângulo é o frontal, o que denota um envolvimento maior. O ângulo oblíquo, por outro lado, transmite a ideia de que "O que você vê aqui não é parte do nosso mundo; é o mundo deles, com o qual nós não estamos envolvidos" (p. 136 - grifo dos autores). Ainda com relação ao ângulo, os participantes nas FIG. 2 e 3 são mostrados na altura dos olhos, o que, segundo os autores (p. 148), indica igualdade com o espectador. Um ângulo alto indicaria um poder maior do espectador; um ângulo baixo, um poder maior do participante.

A distância entre o participante e o espectador também é um indicador de envolvimento. Segundo Kress e Van Leeuwen (2006, p. 125), o close up 
indica maior intimidade e subjetividade. Um campo de visão médio é mais próprio de fotos sociais, enquanto o longo seria mais impessoal. Nesse caso, o close up no rapaz da FIG. 3 indica mais intimidade que na foto da menina da FIG. 2, que está mais afastada e deixa entrever parte do fundo. Situada num contexto, a foto da menina tem um teor mais objetivo que a do rapaz. Ainda assim, o campo de visão utilizado nas duas figuras, a exemplo do ângulo, aproxima o espectador dos participantes em uma relação até certo ponto íntima e igualitária, o que proporciona antes uma identificação que um estranhamento. Essa característica é importante porque, como afirmou Maria Lúcia, membro do MST, a revista é voltada mais para um público externo. É como se os participantes das duas fotos estivessem dizendo: "[v]ejam, somos belos, negros, jovens e sem-terra: somos do MST". Uma espécie de narrativa que ecoa numa das cançôes do movimento, composta em 1997, que diz: "Sou sem-terra, sim senhor! Sou sem-terra com amor" (apud BRANFORD; ROCHA, 2004, p. 329). A imagem da menina transmite ainda um certo ar de inocência e candura, que pode também apelar para um público não tanto afeito às interpelações políticas do movimento.

Considerando-se que grande parte das fotos dos sem-terra tende a apresentar um tom impessoal, objetivo e naturalista - como nas manifestações e ocupações -, as duas fotos acima se destacam pelo seu grau de abstração e subjetividade, principalmente a do rapaz. O tratamento estético adotado enfatiza um ambiente descontextualizado em que o sem-terra como indivíduo se sobrepõe ao coletivo. O fundo sem foco da FIG. 2 e a quase ausência de fundo na FIG. 3 tornam as fotos mais abstratas, tendendo a uma idealização e essencialização dos participantes. Obviamente a abstração é maior na imagem do rapaz, cujo rosto ocupa quase toda a foto. Esse efeito é ainda enfatizado pelo uso do preto e branco e do jogo de luz e sombra. Por outro lado, o close up proporciona uma riqueza maior de detalhes, destacando os traços negros de seu rosto e intensificando o naturalismo. É possível ver com detalhe os pelos das sobrancelhas e as imperfeições da pele, o que dá a sensação de se estar na presença de uma pessoa "real". Um olhar mais cuidadoso revela ainda um detalhe que quase passa despercebido: os fones de ouvido. Lado a lado, na mesma foto, o chapéu de palha - descartado como símbolo pelo MST por ser considerado saudosista - e os fones de ouvido, que situam o participante da imagem no mundo tecnológico atual. A descrição foge ao padrão de imagem tradicional de um trabalhador rural: nada de radinho de pilha ou cigarro de palha. Quanto ao que ele possa estar ouvindo em seus fones, as 
possibilidades são ilimitadas. Na foto da menina, a coloração forte e a presença da mulher em primeiro plano também diminuem a abstração e oferecem um tom mais naturalista. Conforme apontam Kress e Van Leeuwen (2006, p. 163), uma mesma imagem pode ser abstrata de acordo com determinados marcadores e naturalista de acordo com outros. Esses marcadores contribuem para uma avaliação global de modalidade, mas essa tarefa ficará a cargo do espectador.

Modalidade, segundo os autores (p. 166), refere-se ao valor de verdade ou credibilidade associado a uma representação de mundo. Mas ela não pode expressar verdades absolutas, e sim "produzir" verdades que são compartilhadas por um determinado grupo social ou cultural num determinado momento. Assim, as noções de abstração, naturalismo e realismo também variam de acordo com os valores de cada grupo e com o contexto em que o leitor, ouvinte ou espectador entra em contato com um enunciado, seja qual for o modo de produção de significado. Portanto,

[a] Realidade está nos olhos do observador; ou melhor, o que se considera como real depende de como a realidade é definida por um grupo social em particular. [...] Um "realismo" é produzido por um determinado grupo como efeito do complexo de práticas que definem e constituem esse grupo. Nesse sentido, um tipo particular de realismo é em si mesmo um signo motivado, no qual os valores, crenças e interesses desse grupo encontram sua expressão (KRESS; VAN LEEUWEN, 2006, p. 158).

Na FIG. 3, a coloração em preto e branco e o jogo de luz e sombra tornam a foto mais abstrata e, pode-se dizer, reduzem sua modalidade. Esses aspectos podem inserir-se na categoria de orientaçōes de codificação abstrata, que, segundo Kress e Van Leeuwen (2006, p. 165), são usadas pelas elites socioculturais ocidentais, principalmente em termos de uma arte mais refinada. Nesse contexto, continuam os autores, a modalidade é mais alta quando uma imagem reduz o concreto a suas qualidades essenciais. Assim, a capacidade de produzir e / ou ler textos baseados nessas orientaçóes seria uma marca de distinção social: de uma "pessoa educada" ou de um "artista sério". No caso da FIG. 3, o que pode dar a impressão de uma modalidade mais baixa (menos real) para um sem-terra pode ter uma modalidade mais alta (mais real) para grupos que valorizam aspectos estéticos como o jogo de luz e sombra de uma imagem, pois "as pessoas não apenas se comunicam para afirmar como 
verdadeiros os valores e crenças de seu grupo. Elas também se comunicam para estabelecer graus de verdade e não-verdade aos valores e crenças de outros grupos" (KRESS; VAN LEEUWEN, 2006, p. 155). Assim, o oposto também pode ser afirmado. O que, para os sem-terra, expressa realidade em seus textos - principalmente quando se referem a manifestações e denúncias, por meio de uma certa objetividade jornalística - pode, para outros grupos, parecer excessivamente real, o que também contribui para a atenuação da modalidade e, consequentemente, da própria noção do real. A modalidade é, portanto, socialmente motivada (p. 172-173), pois se realiza na transição entre diferentes grupos e entre diferentes pessoas no interior de um mesmo grupo.

A imagem da FIG. 3 assemelha-se a uma obra de arte, como uma pintura ou escultura, e parece dialogar com um grupo com interesses diferenciados, levando-se em consideração também que a Revista Sem Terra é voltada principalmente para um público externo. É como uma tentativa de adotar os valores, crenças e significados desse grupo. Nisso, a foto, assim como a da FIG. 2, assemelha-se muito às que o fotógrafo Sebastião Salgado publicou em seu livro Terra (1997) - cujos participantes são os sem-terra - e que também têm sido utilizadas pelo movimento em seus meios de comunicação. Outro aspecto a se considerar é que as imagens das capas da revista, em geral, não são meros complementos do texto escrito, o que a diferencia da grande maioria das publicações de massa, que costumam relacionar a imagem da capa à notícia em destaque. Isso também pode auxiliar para atrair um público diferenciado, seduzindo-o mais pelo teor da imagem que pelo do texto escrito, contrariando, de certa forma, a afirmação de Maria Lúcia, comentada anteriormente, de que é o "conteúdo" que atrai o leitor, entendido neste caso como conteúdo linguístico. Não que a imagem possa significar por si só, pois ela faz parte de um contexto, no qual se insere também o texto escrito. Como observa Barthes (1977, p. 15), o próprio nome da publicação agrega significado a uma fotografia jornalística. Kress e Van Leeuwen (2006) consideram ainda que as codificaçôes abstrata e naturalista podem ser usadas pela mesma pessoa em situações diferentes, mas as imagens abstratas, para aqueles que não possuem uma educação voltada para elas, nunca terão modalidade alta e "permanecerão sempre 'irreais" (p. 166). Eles se referem a membros da sociedade ocidental atual, o que não quer dizer que membros de outras sociedades e grupos não tenham suas próprias orientações abstratas e uma educação própria para elas. Grupos indígenas brasileiros, como já foi mencionado, fazem uso extensivo das imagens (pinturas) na comunicação. Para 
pessoas de fora do grupo, muitas delas podem parecer irreais, mas fazem sentido - e podem parecer mais naturalistas e, portanto, ter uma modalidade mais alta - para aqueles que foram instruídos a seu respeito (MENEZES DE SOUZA, 2005).

As fotos acima reforçam dois aspectos da identidade do MST. Por um lado, o trabalhador rural identifica-se com os participantes das imagens e, como resultado, orgulha-se do que é. Por outro, identifica-se com um espectador externo, diferente, que também é convidado a identificar-se com o sem-terra. Esse movimento em direção ao outro contribui para a heterogeneidade do sem-terra e, para que haja esse diálogo, é necessário que ele seja também proficiente na linguagem do outro. Entretanto, educar-se numa linguagem abstrata, mais propícia de uma arte dita refinada e identificada com uma certa elite social, não significa progredir ou avançar culturalmente, o que seria típico de uma visão linear e positivista, considerando-se ainda que qualquer julgamento estético é relativo e depende de um contexto. Assim, ao fazer uso da linguagem abstrata, o MST agrega valores à sua identidade e tem acesso a uma representação estética mais diversa, a exemplo do uso da língua culta em suas mídias. A proficiência no uso dessa linguagem é, portanto, um fator de heterogeneidade e empoderamento, pois amplia as possibilidades de autorrepresentação do movimento e o acesso a públicos diferenciados.

\section{Realismo e representação em fotos e legendas}

Ainda com respeito à discussão sobre realismo, as fotos do MST a serem analisadas a seguir apresentam uma curiosa relação com suas legendas. Conforme já foi exposto anteriormente, os responsáveis pelas mídias do MST fizeram uma opção consciente de privilegiar fotos que mostrem o engajamento dos sem-terra, ainda que elas retratem eventos e circunstâncias distintas daquelas que elas supostamente estão ilustrando. As legendas, neste caso, podem ser reveladoras. Segundo Barthes (1977, p. 16), toda fotografia jornalística está em comunicação com o texto que a acompanha: o título, a legenda, o artigo. 


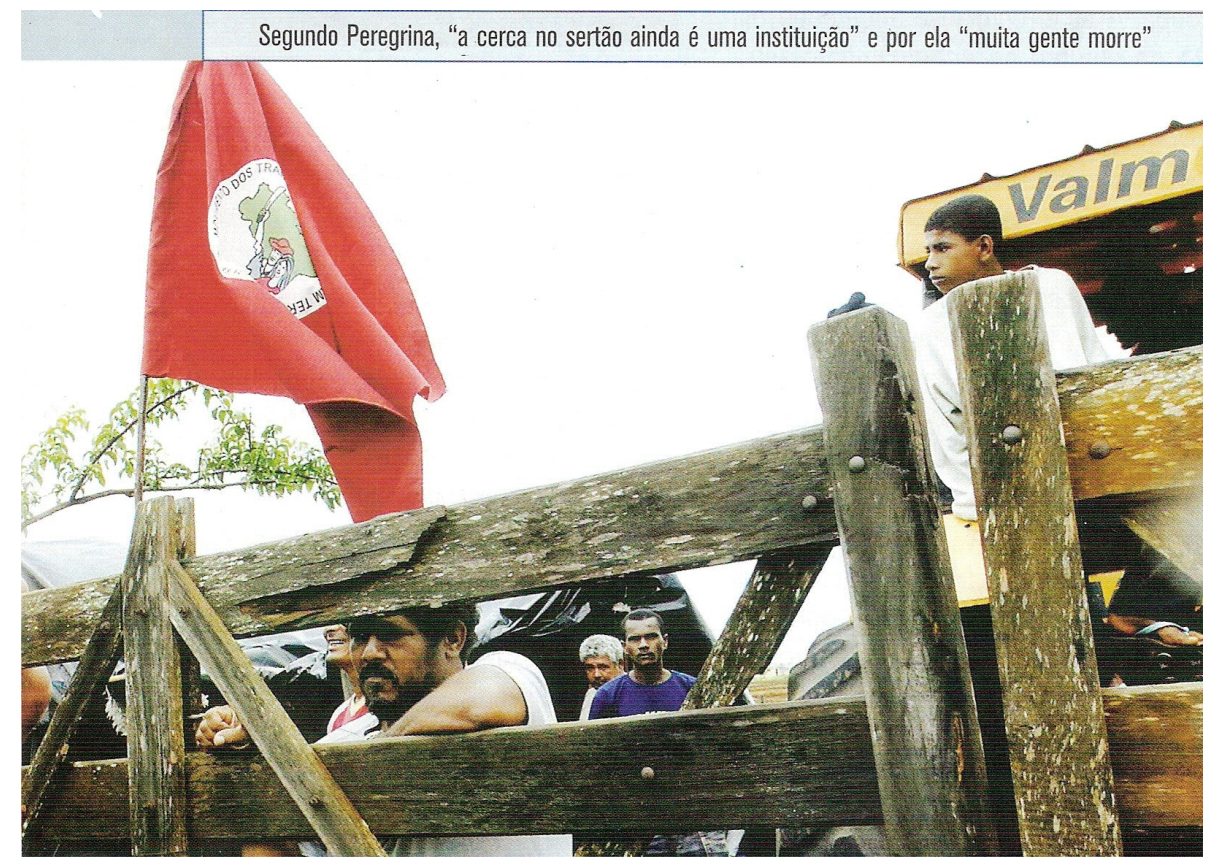

FIGURA 4 - Cerca

Fonte: Revista Sem Terra, nov./dez. 2007, p. 8.

Considere-se, por exemplo, a foto da figura 4. Ela está inserida numa entrevista com a socióloga cearense Peregrina Cavalcanti, que fala sobre o crime de pistolagem no Brasil. $\mathrm{Na}$ entrevista, a socióloga refere-se a uma cerca qualquer que separe duas propriedades e que pode se tornar fonte de conflito entre as famílias proprietárias por dezenas de anos (CAVALCANTI, 2007, p. 6). A foto, por sua vez, exibe membros do MST - conforme se pode inferir pela presença da bandeira - separados por uma cerca, mas não se sabe de quê. Ao que tudo indica, trata-se de uma propriedade, o que é suficiente apenas para especular de que lado da cerca estão os sem-terra. Eles podem estar dentro da propriedade, talvez ocupada ou transformada em assentamento. Ou fora dela, aguardando uma oportunidade para ocupá-la. O participante em posição de destaque apoia-se sobre a porteira como se estivesse em uma prisão. Seja de que lado da cerca ele estiver, a possibilidade de interlocutores do outro lado são inúmeras: a polícia, os proprietários, a imprensa, jagunços, trabalhadores da fazenda. Seu olhar forma um vetor em direção ao desconhecido. Trata-se de uma reação não-transacional (KRESS; VAN LEEUWEN, 2006, p. 68), 
intensificada pelo vetor formado pelo olhar do rapaz em cima do trator, que aponta para outra direção e proporciona dinamicidade à foto. Nesses casos, segundo Kress e Van Leeuwen, fica a cargo do espectador imaginar o que eles estão pensando ou para onde estão olhando. Esse recurso pode, portanto, tornar-se fonte de uma manipulação representacional. Uma legenda, continuam eles, pode "sugerir algo para o qual o Reator está olhando, mas, desnecessário dizer, não precisa ser aquilo para o qual o Reator estava de fato olhando quando a foto foi tirada" (p. 68). Referindo-se a imagens em movimento, Manovich (2001, p. 149) fala de uma montagem temporal, que ele chama de "montagem ideológica" e que vai além da construção de uma ficção artística, estando presente também em documentários, comerciais e noticiários. O pioneiro dessa técnica, segundo ele, é o cineasta russo Dziga Vertov, que editava episódios de seu programa de notícias Kino-Pravda ("Cinema-Verdade") a partir de cenas filmadas em locais e épocas diferentes.

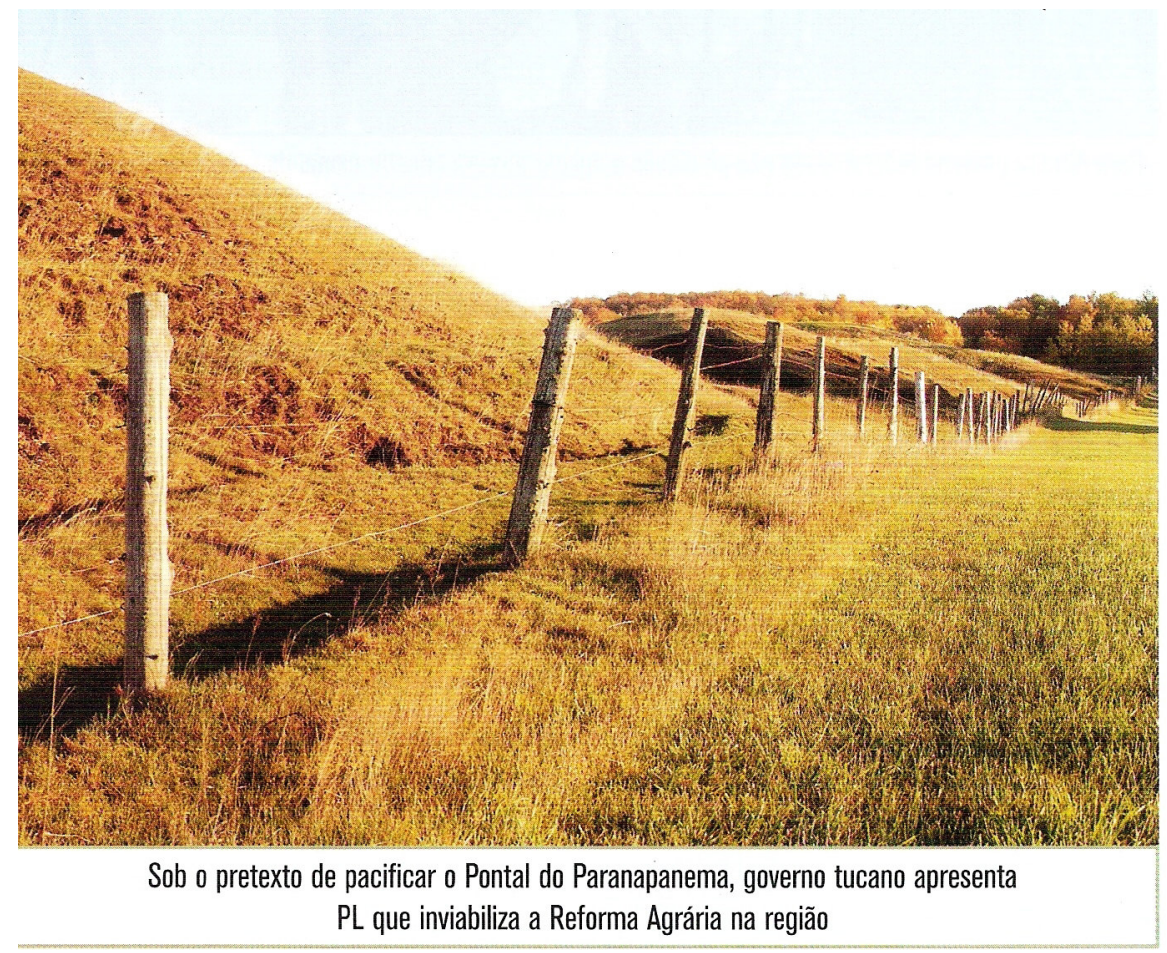

FIGURA 5 - Cerca

Fonte: Revista Sem Terra, set./out. 2007, p. 14. 
O tema da legenda, na foto do MST (FIG. 4), é a cerca, e ela está na foto. No entanto, pode-se dizer que não se trata da mesma cerca. Deliberadamente, os editores retiraram do texto uma frase e a reutilizaram num outro contexto, que enfatiza o conflito agrário a partir da ótica dos sem-terra e não como uma disputa entre famílias. A presença dos sem-terra na foto suscita uma discussão em torno da reforma agrária e da participação ativa do MST nesse processo. Assim, a cerca adquire outra simbologia, pois sua relação com o problema fundiário brasileiro é clássica e tornou-se quase que um símbolo de latifúndio. Ela não apenas cerca, mas também separa e, portanto, adquire o significado de exclusão e acesso interrompido. Se o participante em destaque na imagem parece estar numa prisão, ele mais provavelmente está do lado de fora e não de dentro da cerca. Por isso, ela se concretiza como o obstáculo a ser transposto, tanto literal quanto figurativamente. Vejam-se, ainda, expressóes como "Romper a cerca do analfabetismo" (PEREIRA FILHO, 2007) e "Rompendo a cerca” (BRANFORD; ROCHA, 2004), empregadas para tratar de assuntos relacionados à luta do MST. Já na FIG. 5, ela simboliza a impossibilidade da reforma agrária. É para esse universo todo que as fotos parecem remeter o leitor/ espectador. A relação entre imagem e texto escrito, neste caso, como em muitos outros, assume proporções conflituosas:

Dado que as sociedades não são homogêneas, mas compostas de grupos com interesses variados, e geralmente contraditórios, as mensagens produzidas pelos indivíduos vão refletir as diferenças, incongruências e embates que caracterizam a vida social. É provável e pela nossa experiência é o que geralmente acontece - que os diferentes modos pelos quais os textos são construídos mostram essas diferenças sociais, de maneira que, num texto multimodal usando imagens e escrita, a escrita pode transmitir um conjunto de significados e as imagens, outro (KRESS; VAN LEEUWEN, 2006, p. 20). 


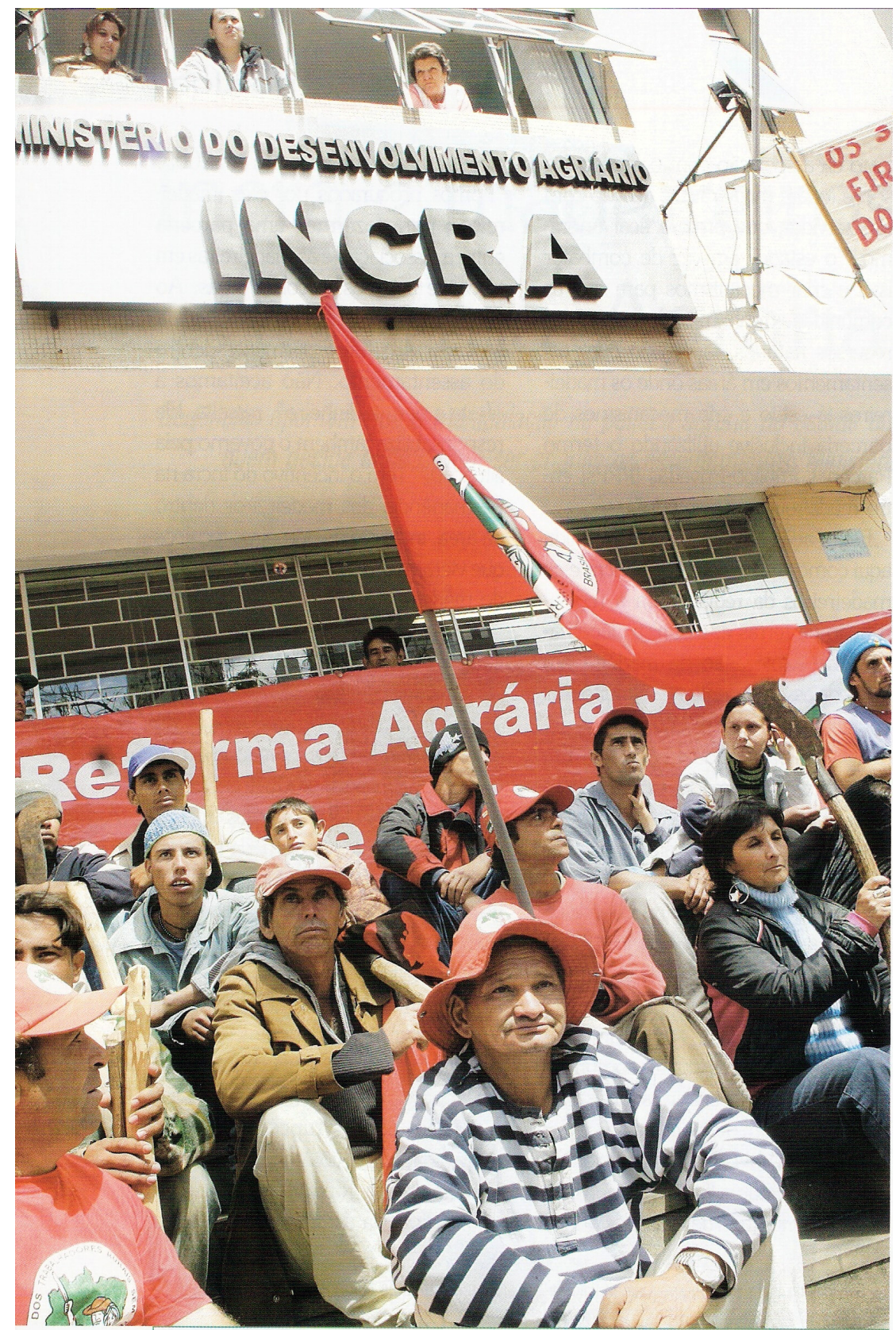

Servidor do Incra denuncia que a Reforma Agrária na região tem se desviado de sua finalidade

FIGURA 6 - Manifestação em frente ao INCRA

Fonte: Revista Sem Terra, nov./dez. 2007, p. 12. 
Esse conflito parece se repetir ainda em outras imagens utilizadas pelo movimento. Na FIG. 6, os manifestantes estão sentados de costas para a entrada do prédio do Instituto Nacional de Colonização e Reforma Agrária (INCRA). A maioria dos olhares dirige-se para algum ponto desconhecido. Algo está acontecendo fora da imagem, mas não se sabe o quê, como na FIG. 4. A imagem integra uma matéria que critica a maneira como o órgão do governo vem conduzindo a reforma agrária no país (FIDELES, 2007). A legenda, entretanto, destaca o ponto de vista de um servidor do INCRA que também discorda dessa política. $\mathrm{O}$ artigo como um todo mostra que há conflitos e contradiçōes no interior do órgão governamental. A FIG. 6, por sua vez, ressalta uma situação em que o MST está de acordo com a voz dissonante. Já a leitura da imagem somente, sem a legenda, faz supor que não há conflito entre o MST e o INCRA. Os manifestantes estão sentados de costas para o prédio, como se formassem um mesmo sujeito, que contempla o infinito. A bandeira do movimento forma um vetor que conduz o olhar do espectador para o nome do instituto. A leitura do conjunto imagem-legenda confirma o potencial de produção de significados da multimodalidade, entendida como "a aproximação ou justaposição de diferentes modos de comunicação [...] para criar um efeito específico ainda não disponível em qualquer um dos modos específicos em questão" (MONTE MÓR, 2006, p.133). Essa foto enfatiza ainda a política dos jornalistas do MST de incluir fotos em seus meios de comunicação que mostrem o sem-terra em situações de ativismo. A matéria é sobre o INCRA, mas os sem-terra também estão lá na foto. Há um duplo processo metonímico: o "servidor do INCRA" na legenda está para o próprio instituto na foto, e os sem-terra na foto representam a "Reforma Agrária" da legenda.

Nas FIG. 4, 5 e 6, pode-se dizer que há uma fratura entre a legenda e a foto, entre o verbal e o visual. Rodowick, comentando, via Michel Foucault, a pintura "Ceci n'est pas une pipe", do belga René Magritte (MAGRITTE, 1929), conclui que "[a] pintura não pode ser reduzida a uma unidade. Dividida entre figura e texto, continua separando, bifurcando e reconstituindo possibilidades de significação" (RODOWICK, 2001, p. 66). No caso das FIG. 4, 5 e 6, essa fratura implica ao menos duas possibilidades. Por um lado, elas se configuram como montagens jornalísticas, que relativizam a própria intenção do editor de representar a realidade. Por outro, despertam um certo estranhamento e distanciamento, nos moldes do teatro brechtiano, que pode "demandar" uma postura mais crítica do leitor. Da mesma forma, o texto escrito na FIG. 3 acima pode evitar que o leitor enxergue a foto apenas como um objeto estético num mundo idealizado. 


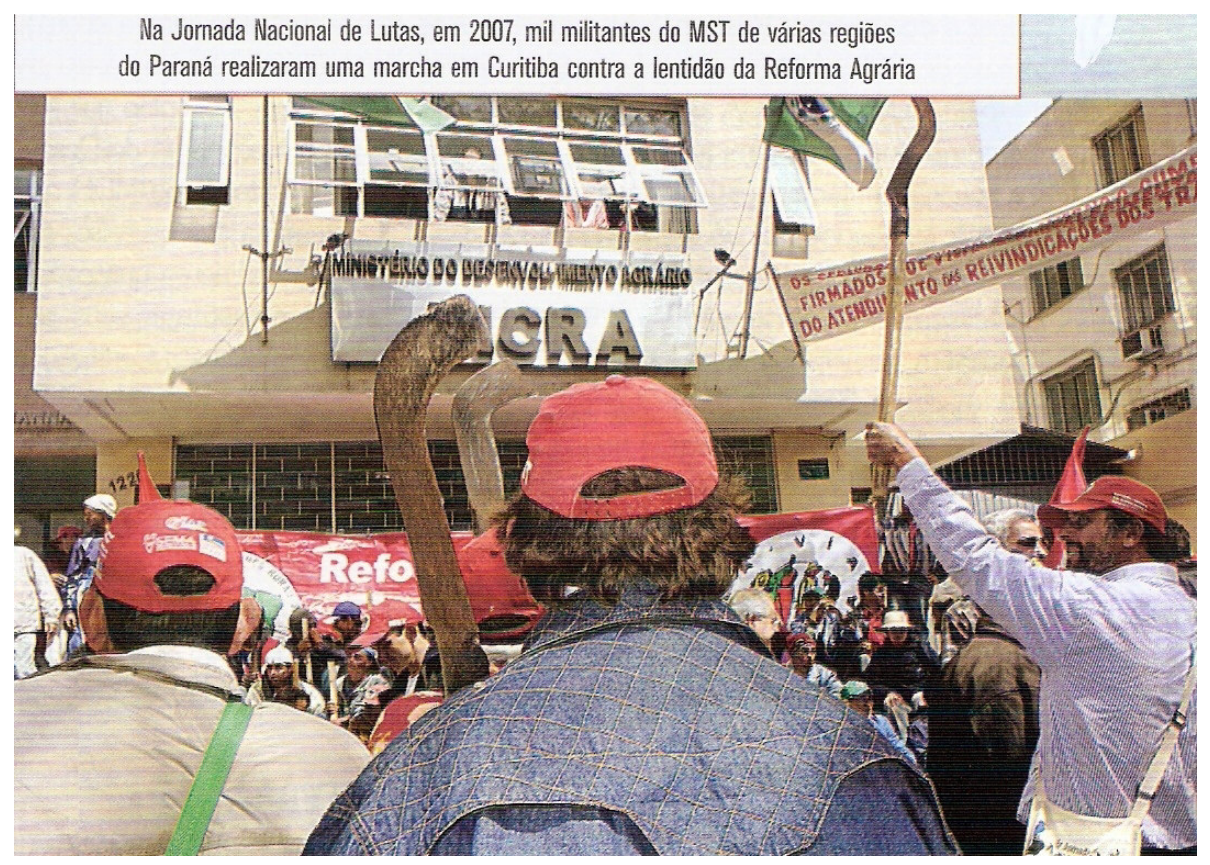

FIGURA 7 - Manifestação em frente ao INCRA.

Fonte: Revista Sem Terra, jan./fev. 2008, p. 9.

A FIG. 7 mostra a mesma manifestação exibida na figura anterior, mas de outro ponto de vista. Imagem e legenda parecem falar do mesmo evento. Dessa vez, todavia, com base na disposição espacial e postural dos manifestantes, os sem-terra se posicionam contra o INCRA. Em destaque, estão participantes de costas para o espectador e de frente para o prédio do instituto, como que o desafiando. Em vez da bandeira, há foices formando vetores em direção ao nome do instituto. A imagem apresenta uma ação transacional que forma um processo narrativo segundo o qual os manifestantes são os atores, as foices são o meio e o prédio, a meta, de acordo com as definiçóes de Kress e Van Leeuwen (2006, p. 74-75). As FIG. 6 e 7 representam, portanto, um mesmo evento, com duas imagens e duas situações diferentes. Na primeira, o INCRA é apresentado como um aliado em potencial. Na segunda, como um não-aliado. Esse conflito de certa forma ilustra a relação que o MST mantém com o governo, que ora é de aproximação, ora de distanciamento. 


\section{Considerações finais}

As figuras analisadas na seção anterior evidenciam o potencial de manipulação no uso de imagens na mídia. O MST procura representar-se como um grupo de ativistas e lutadores e enfatiza esse aspecto em grande parte de suas imagens, mesmo que elas entrem em conflito com o texto escrito. Entretanto, "a realidade está nos olhos do observador" (KRESS; VAN LEEUWEN, 2006, p. 158), cuja interpretação dependerá da avaliação global da modalidade e dos modos de representação que ele inferir do texto como um todo. De qualquer maneira, fica evidente que ao menos o setor de comunicação do movimento demonstra uma forte competência multimodal, principalmente para lidar com o poder de significação das imagens. Essa competência não é aplicada com tanto vigor em seu website, onde as imagens são pouco exploradas, com predominância massiva do modo linguístico. Mesmo assim, a produção midiática do MST tem se diversificado consideravelmente, recorrendo ao vídeo, teatro, fotografia e rádio como meios de produção de significados, o que demonstra um crescente domínio dos recursos da multimodalidade e dos multiletramentos. Como essas habilidades estão pressupostas em todo o processo comunicativo, o papel de receptor do texto também assume grande relevância e contribui para a formação crítica do sujeito. Nesse caso, o sem-terra exerce sua competência multimodal tanto na produção quanto na recepção do texto.

Além disso, como já mencionado anteriormente, o processo de identificação se dá em dois níveis, o interno e o externo. Internamente, o uso das imagens como modo de produção de significados fornece elementos de coesão grupal e instiga o sem-terra a identificar-se coletivamente. Ao mesmo tempo, o MST lança um olhar para fora e dialoga com sujeitos individuais e coletivos externos ao grupo, identificando-se com eles e convidando-os a identificar-se com o movimento. Esse último caso em especial é fonte de grande empoderamento, pois exige do sem-terra a proficiência na linguagem do outro - ampliando assim seu horizonte de atuação - e contribui para intensificar sua já abrangente heterogeneidade. A construção multimodal da identidade do sem-terra, por fim, pressupõe que a tensão e o conflito na autorrepresentação e na ação social provenientes dessa heterogeneidade têm seu correlato também no entrelaçamento dos diversos modos de produção de significados que o movimento utiliza. Para isso, há que se pensar no texto multimodal não como um produto acabado cujas partes se integram com perfeição, mas como portador de significados em permanente movimento e transformação. 


\section{Referências}

ABOUT the MST. Disponível em: <http://www.mstbrazil.org/?q=book/print/16>. Acesso em: 23 dez. 2006.

BARTHES, R. Image, music, text. Trad. Stephen Heath. New York: Hill and Wang, 1977.

BRANFORD, S.; ROCHA, J. Rompendo a cerca: a história do MST. Trad. Rubens Galves Merino. São Paulo: Casa Amarela, 2004.

BRASIL. Secretaria de Educação Básica. Orientaçôes Curriculares para o Ensino Médio: linguagens, códigos e suas tecnologias. v. 1. Brasília: MEC / SEB, 2006. p. 85-124.

CASTELLS, M. O poder da identidade. Trad. Klauss Brandini Gerhardt. São Paulo: Paz e Terra, 1999.

CAVALCANTI, P. A pistolagem é a cara da história do Brasil. Entrevista concedida a Beatriz Pasqualino. Revista Sem Terra, São Paulo, n. 42, p. 5-8, nov.-dez. 2007.

COPE, B.; KALANTZIS, M. Introduction: Multiliteracies: the beginnings of an idea. In: COPE, B.; KALANTZIS, M. (Ed.). Multiliteracies: literacy learning and the design of social futures. London: Routledge, 2000. p. 3-8.

FIDELES, N. Incra e madeireiros distorcem Reforma Agrária no Pará. Revista Sem Terra, São Paulo, n. 42, p. 10-13, nov.-dez. 2007.

GOHN, M. G. Mídia, terceiro setor e MST: impactos sobre o futuro das cidades e do campo. Petrópolis: Vozes, 2000.

HISTORY of the MST. 12 fev. 2003. Disponível em: <http://www.mstbrazil. org/?q=book/print/16>. Acesso em: 23 dez. 2006.

KRESS, G. Multimodality. In: COPE, B.; KALANTZIS, M. (Ed.). Multiliteracies: literacy learning and the design of social futures. London: Routledge, 2000. p. 182-202.

KRESS, G.; VAN LEEUWEN, T. Reading images: the grammar of visual design. 2. ed. Abingdon: Routledge, 2006.

MAGRITTE, R. La trahison des images. 1929. 670px $\times$ 514px. $173.66 \mathrm{~Kb}$. Formato JPEG. Disponível em: <http://en.wikipedia.org/wiki/File:MagrittePipe.jpg>. Acesso em: 22 maio 2009.

MANOVICH, L. The language of new media. Cambridge, Mass.: MIT Press, 2001. MENEZES DE SOUZA, L. M. T. The ecology of writing among the Kashinawá: indigenous multimodality in Brazil. In: CANAGARAJAH, A. S. (Ed.). Reclaiming the local in language policy and practice. Mahwah: Lawrence Erlbaum Associates, 2005. p. 73-95. 
MONTE MÓR, W. Reading Dogville in Brazil: image, language and critical literacy. Language and Intercultural Communication, v. 6, n. 2, p. 124-135, 2006. MULHER sem terra na luta pela reforma agrária. 25 ago. 2006. Disponível em: $<$ http://www.mst.org.br/mst/pagina.php?cd=1875>. Acesso em 29 mai. 2007. PEREIRA FILHO, J. Romper a cerca do analfabetismo. Brasil de Fato, 28 jun. 2007. Disponível em: <http://www.mst.org.br/mst/pagina.php?cd=3825>. Acesso em: 29 jul. 2008.

QUIRK, P. W. How to be a good friend (when you are 4,000 miles away). 24 set. 2007. Disponível em: <http://www.mstbrazil.org/?q=quirkonfmstsolidarityefforts>. Acesso em: 1 out. 2007.

RODOWICK, D.N. Reading the figural, or, philosophy after the new media. Durham: Duke University Press, 2001.

SALGADO, S. Terra. São Paulo: Companhia das Letras, 1997.

Recebido em março de 2009. Aprovado em maio de 2009 